\title{
Decentralization from Above, Dispossession by Recognition: Contradictions in Tanzania's New Wave Land Reforms
}

\section{Juan José del Valle Coello}

Faculty Mentor: Dr. Maria Groz-Ngaté, Department of African Studies Indiana University

\section{ABSTRACT}

Recent decades have seen a surge in land reform throughout Sub-Saharan Africa, largely described as "new wave" land reforms aiming to promote rural development through decentralization and formal recognition of claims to land. Focusing on Tanzania, a country with historically highly centralized land management, this investigation examines how new legislation, in particular the 1999 Village Land Act, has attempted to address both local concerns and international pressures and evaluates how successful reforms have been in terms of both. This paper analyzes these reforms in the context of neoliberalism and the related "pro-poor growth" model, which advocates for the formalization and marketization of land titles as a long-term solution to rural poverty. It first provides a theoretical background on the debates surrounding land reform strategies and then examines specific examples from reforms in Tanzania.

Tanzania's reforms have been guided both by local grievances (such as lack of clarity and security regarding access to land) and international pressures (desiring, among other things, greater ease of foreign investment and the creation of a rural land market); as such, issues have frequently arisen in attempting to reconcile sometimes contradictory demands and determining priorities. The results of reforms have been mixed. Formalization, in particular, has shown the potential to exacerbate inequality instead of reducing it, and the process of formalization itself can lead to an increase in conflict over land. However, reforms have also opened new avenues for previously marginalized groups, such as pastoralists, to secure land access through participation in civil society.

\section{KEYWORDS: land reform, land grabbing, Sub-Saharan Africa, Tanzania, new wave, formalization}

\section{INTRODUCTION}

$\mathrm{F}_{\mathrm{p}}^{\mathrm{o}}$ llowing the transition from state-centered development plans to a neoliberal framework and the "rule of law," the past few decades have seen a surge in land-related reforms in Sub-Saharan Africa. These reforms have been characterized by a push for the formal recognition of land tenure rights (including customary rights), greater transparency and clarity in legislation concerning land, the creation of efficient land markets, and decentralized land management. In Tanzania specifically, a country with a history of highly centralized and undemocratic land control, reforms starting in the late 1980s have attempted simultaneously to address demands from previously disenfranchised groups and implement reforms advocated by international financial institutions and development agencies. This attempt to use reforms to address local concerns while simultaneously pleasing investors and meeting international expectations has resulted in contradictions both in policy and outcome. While these reforms have demonstrated success in many instances and potential for future improvement in others, they have also aggravated problems at times and led to more, not less, confusion regarding land tenure; implementation, moreover, has been an issue in itself. This investigation focuses primarily on Tanzania's landmark 1999 Village Land Act, a central reform, though not the only one that took place at the time. It also examines occurrences since then, examining the conditions that led to its design and the roles of different actors. Situating the reforms in a theoretical framework of "pro-poor growth," it reviews the literature surrounding recent African land reforms and then focuses on Tanzania, bringing in examples from different case studies bearing on the Act's implementation, or lack thereof.

\section{TERMINOLOGY AND CONTEXT}

A brief definition of some terms related to landholding is appropriate before a discussion of land reforms. Key distinctions are "customary" versus "granted" rights and "land ownership" versus "land tenure." In the Tanzanian context, land refers to the surface of the earth, everything underneath other than petroleum and minerals, and everything on top of the land (water, plants, buildings, etc.). Land tenure, which is the applicable description for the Tanzanian system, signifies the manner in which residents have claim to the land; they do not ultimately own the land that is in their name, but they do have the right to occupy and use it for a specific amount of time (typically ninety-nine years); all land in Tanzania is ultimately public land, held by the president in trusteeship for the "benefit of the nation" (Rwegasira, 2012). Finally, the definition of customary rights to land is politically significant; while in general it refers to rights deriving their legitimacy from tradition and historical tenure, in Tanzania the working definition is "the current land usage patterns in village land" (Fairley, 2012, p. 8). Granted rights, in contrast, are those which are explicitly given by the government to an individual who previously did not have claims to them (Rwegasira, 2012).

Tanzania's new land reforms have been described as "new wave" land reforms. As defined by Rasmus Pedersen of the Danish Institute for International Studies (DIIS), new wave reforms consist of three elements, all of which 
are present in the Tanzanian case: an immediate recognition of existing (customary) claims to land, decentralization, and formalization (formal/official recognition and recording) of land claims, which ideally both improves tenure security and facilitates the creation of land markets. This contrasts with previous land reforms, which focused on land nationalization, redistribution, and/or individualization of land tenure and an abandonment of customary rights (Tanzania's New Wave Land Reform, 2014).

*The reforms discussed in this essay concern solely mainland Tanzania. Zanzibar (an autonomous region within Tanzania) has its own land tenure system, which will not be discussed here.

**Although it may be somewhat imprecise, for the sake of convenience, the word "landholder" or "land user" will be used here to refer to those living on and using a tract of land, regardless of whether they have formal rights/ownership or not.

\section{THE HISTORY OF LAND TENURE AND LAND LAW IN TANZANIA}

Land law and land tenure systems in Tanzania, as throughout Sub-Saharan Africa, bear a strong imprint of a tumultuous history, displaying the legacy of pre-colonial, colonial, and post-colonial systems and the transformations associated with each of them. Prior to German occupation, there existed various land tenure systems associated with the political structure of different societies; specifically in agricultural societies, land was generally managed under communal or feudal systems, with local authorities such as chiefs controlling distribution and resolving conflicts. Upon occupation, German colonizers recognized indigenous claims to land native populations inhabited or used, but they transferred all unoccupied territory to the Crown. Additionally, they excluded native inhabitants from purchasing land, and customary land tenure, while recognized, was given inferior treatment as landholders were not able to access registries. The British, who took over Tanganyika (mainland Tanzania) after World War I, maintained a system of indirect rule through local chiefs, maintaining many groups marginalized and forcibly resettling some populations (Rwegasira, 2012).

After Tanganyika's obtaining independence in 1961 and merging with Zanzibar to form Tanzania in 1964, land administration changed significantly. Tanzania's first Prime Minister, Julius Nyerere, viewed the traditional land system largely controlled by local chiefs as inimical to his ideas of Ujamaa (African socialism), national unity, and economic modernization. Maintaining the colonial policy of vesting all land ownership in the central government, he stripped these chiefdoms of their political power and nationalized all land, although chiefdoms continued to have an important informal role (Pedersen, 2015). In its first post-independence decades, Tanzania experienced a significant degree of agricultural collectivization and forced resettlement as part of its "villagization" program, which entailed the designation of socialist villages (vijiji vya ujamaa) and at times violent coercion of citizens into resettling there. New villages and boundaries were drawn and formalized as part of this policy in 1975, and locally accountable village councils were formed in order to manage them. Already by the early 1980 s, however, there were clear signs of problems stemming from the government's centralization; among other things, agricultural productivity had fallen precipitously. As such, Tanzania started moving away from the steadfast socialist policies it had maintained previously; it greatly eased the restrictions on private enterprise and started allowing private land ownership and a new market in land in 1983. This new market, in combination with a lack in legal infrastructure to handle it, led to an upsurge in land-related disputes by the late 1980s, prompting the national government to start considering a systemic overhaul. It appointed a Presidential Commission, headed by Tanzanian legal scholar Issa Shivji, to investigate land disputes and propose solutions. The report advocated, among other things, for far-reaching devolution of control of land matters to local governments and for the establishment of a clear and functional mechanism for the resolution of land disputes. These steps, which had begun in the 1980s, arguably culminated in the passing of the 1999 Land Acts, which included both a Village Land Act dealing with village, i.e., most rural land, and a Land Act, which dealt with urban land and other land not covered by the Village Land Act. Shivji's proposals were heeded up to a point but did not involve the extent of decentralization he desired; ultimately, the acts were drafted with the help of international consultants (who received funding from the World Bank and British government) and followed the recommendations of the Minister of Lands, Housing, and Human Settlement Development (hereafter referred to as Minister of Lands) (Pedersen, 2015).

\section{THE 1999 VILLAGE LAND ACT: A SUMMARY}

Praised by many for its progressive nature, the 1999 Village Land Act, together with its accompanying 1999 Land Act, has been a major source of discussion and study within the development sphere. Aiming to devolve control (i.e., return a greater degree of control to lower/more local levels of government), clarify the rights and responsibilities of different stakeholders, and strengthen the land rights of villagers (in particular commonly marginalized groups, such as women and pastoralists), the act did away with the last remnants of British law remaining in the Tanzanian system. Key points of the (quite extensive) law include the following: the redesignation of the Village Council (elected every five years by an assembly in which all village adults can participate) as "land manager" instead of the "land owner" it previously was; a pathway for the formalization of customary claims to land, as well as safeguards for customary landholders that do not wish to formalize their claims; the requirement for the central government to provide compensation for the very 
land itself taken from residents in addition to the crops and buildings on it; the delineation of different categories of land; and the mechanisms for villages and individual residents to determine their territorial boundaries, among others (Wily, 2003). Shortly afterward, in 2002, Tanzania also passed a Land Disputes Settlement Act as part of this same "wave" of reforms.

\section{THE NEOLIBERAL APPROACH TO LAND}

A discussion of Tanzanian land reforms should be placed in a global context; after all, Tanzania is but one of the many countries in Sub-Saharan Africa carrying out major land reform, and many of the tendencies visible in the reforms are inextricably linked to major worldwide trends, including neoliberalism and new approaches to development. In the "Postface" to his book The Road from Mount Pèlerin: The Making of the Neoliberal Thought Collective, historian Philip Mirowski enumerates eleven axioms of neoliberal philosophy, providing a definition of neoliberalism that recognizes its epistemic as well as economic characteristics. Among these tenets he lists the necessity for the deliberate construction of a market state, which must thereafter be presented as the "inexorable" state of society; reliance on the market as the ultimate allocator of goods and services; the promotion of a highly circumscribed definition of "freedom" and a view of individuals as atomistic, rational actors; and the presentation of neoliberal ideas as a "moral code" (2009). Using this understanding, the reforms advocated by international development agencies and financial institutions largely fit within the neoliberal framework, while demonstrating some divergence. As described by legal scholar Ambreena Manji, land reform in Tanzania (and indeed throughout Africa) has largely concentrated on diffusing a normative view of individual, legally defined rights to land, in combination with functioning land markets. However, perhaps a more appropriate term is "pro-poor growth," which recognizes the importance of functioning markets as a key to improvement in living standards but also focuses explicitly on reducing income inequalities and protecting marginalized groups (on the other hand, many definitions of neoliberalism, including Mirowski's, specifically list inequality as a necessary condition). Pro-poor growth, as well as neoliberal reforms in general, commonly appeal to an ideal of "good governance," viewed as necessary for the functioning both of society and markets, including adherence to contracts, transparency, etc. (Federal Ministry for Economic Cooperation and Development, 2006).

A major influence on land reform in the pro-poor context has been the work of Peruvian economist Hernando de Soto. A vigorous proponent of land title formalization, de Soto has argued that land title formalization provides legal and financial certainty for landholders. This certainty affords them the security to carry out long-term investments on their land, increasing productivity in the long run.
Furthermore, formal titles to property could potentially enable owners to put this property up as collateral to take out loans, which can be used for various purposes, including investment in entrepreneurial activities. His views have been espoused enthusiastically by the World Bank and the British Department for International Development (DFID), which, among others, have started to advocate for such an approach (Stein \& Cunningham, 2015).

\section{CRITICISMS OF THE “NEW WAVE” APPROACH}

The role of legal reform as a catalyst for development is not unproblematic, as many critics readily point out. In her book The Politics of Land Reform in Africa, Ambreena Manji argues that recent land law reforms (the "new wave reforms" mentioned earlier) serve as a way to avoid dealing with land redistribution, which in her view is what is truly necessary to solve problems of inequity. A major criticism of this legalistic approach is its imposition of Western concepts out of context: according to Manji, reforms aiming to establish "rule of law" are explicitly promoted by industrialized capitalist countries to force the developing world into capitalist labor relations, the lack of which is largely considered to be a major cause of underdevelopment (2006). Furthermore, the imposition of rule of law and capitalism follows an "evolutionary" model of thinking, whereby countries are seen to be at various stages of development, with the ultimate (and inevitable) goal of reaching the state of development of Western countries. While in and of itself this approach opens itself to criticism, Manji also argues for a distinction between using the rule of law as a method of development and seeing it as an end goal of development, a distinction that, in her view, proponents of rule of law collapse. She describes a debate between Issa Shivji and British legal scholar Patrick McAuslan on the appropriate role of legislation in land reform: while McAuslan (who has served as a legal consultant for land reforms in East Africa) advocated for a more detailed, explicit, and expansive body of laws dealing with all aspects of land tenure issues in Africa, Shivji argued for more concise laws allowing local officials and administrative bodies more discretion in order to better address localized problems (Manji, 2006). It bears repeating that both Shivji and McAuslan vociferously opposed abuse of governmental power; however, they differed in their view of the solution, with McAuslan placing trust in the capacity of the legal system and Shivji in local actors.

A third point of criticism commonly leveled at neoliberal reforms, and indeed any reform implemented out of its original context, is their simplistic assumption of actors' motivations and, even more basically, homogeneity (indeed, as described by Mirowski, a view of humans as "atomistic" and rational actors). This erroneous assumption becomes evident at many levels: the village, the household, 
different users, etc. One issue is the oversimplification of user rights in many African land regimes. In many contexts, various users can enjoy different types of rights to land; these include primary rights, such as the right to undertake cultivation, secondary rights, such as grazing or gathering other resources after harvesting is complete, and/or seasonal rights (Stein \& Cunningham, 2015). Formalization programs typically acknowledge only primary rights and thus exclude users with other types of rights, essentially "enclosing" land that may have provided them with necessary safety nets; as the poor in particular may depend on non-primary rights, the oversimplified formalization of land titles may have the effect of rendering them more vulnerable. A second homogenizing assumption typical of formalization programs is that of equal economic status of rural inhabitants. Claims to land in informal tenure systems often overlap, and formalization, being a costly procedure requiring access to information and officials, can favor those with the means to acquire formal land titles. In the process, poorer land users can become disenfranchised, a situation which replicates and exacerbates inequality, as it legally blocks the informal access poorer users may have previously had to land (Stein \& Cunningham, 2015). Finally, land law reforms are notorious for their assumptions of intra-household homogeneity. In her book, Manji argues that a primary reason owner-operated farms are viewed as more efficient than farms operated by waged labor is that owners of farms need not pay themselves, thus avoiding hiring, management, and labor-related expenses. However, it is women who often bear the greatest burden in agricultural work but men who typically have both legal and domestic power. As such, without very explicit precautions, such as co-titling of land to both male and female household members, formalization can legally facilitate the exploitation of women, who can be shut out of the process. Different countries have taken various measures to combat the problem of gender inequality in land access, including co-titling requirements and female representation in village councils, but Manji describes these as unsatisfactory, going so far as to argue that intensified productivity is itself predicated on the need for female exploitation (2006).

Another major objection raised by many to new wave reforms is the increased vulnerability of landowners to dispossession. In her work, Manji questions the advisability of exposing smallholders to losing their one productive resource, land; putting up land as collateral for investments, while potentially beneficial for those smallholders successful in their investments and entrepreneurial activities, places owners at the risk of falling in debt and losing their land. Finally, formalization of land claims involves the drawing and legal recognition of boundaries; observers fear that these boundaries have in many instances been drawn in a way that alienates villagers from land previously accessible to them for the purpose of purchase by outside investors (Stein \& Cunningham, 2015).

\section{EVIDENCE FROM TANZANIA: THE NEW REFORMS, BENEFITS, DRAWBACKS, AND CASE STUDIES}

The situation of small landholders in Tanzania has continued to be quite mixed since 2001, when the Village Land Act came into force. There have been improvements for some, but many elements are still found lacking, and both policy and practice have been riddled with contradictions and inconsistencies. One of the criticisms of the land act is its awkward combination of decentralized decision-making with highly centralized, and arguably undemocratic or inefficient, elements. For instance, Village Councils can approve or reject transfers of village land of sizes up to 250 hectares; however, any transfer greater than that is handled by the Minister of Lands, and the village has no say in the matter, even though, logically, the village would be more affected by a larger transfer than a smaller one. Additionally, although Village Councils are in charge of authorizing most proceedings that take place, all Certificates of Customary Rights of Occupancy (CCROs), which formalize customary claims to land, must be signed by the District Land Officer; since districts have an average of approximately eighty villages (if one divides the number of villages in Tanzania by the number of districts), this requirement significantly slows down the process (Wily, 2003). A third issue is an unclear definition of customary law: the land act explicitly acknowledges the legitimacy of traditional/customary ways of handling land and allows for their use, as long as they do not discriminate against marginalized groups or conflict with any other applicable law. However, it defines "customary" in terms of the previous twelve years (presumably because of the complexity of the rural transformations that took place shortly before 1987, i.e. during villagization). This definition does not make clear what customary laws are to be followed in case of divergent opinions as to what constitutes tradition (Wily, 2003); this fact can lead to institutional competition, in which landholders can choose to appeal either to formal or informal methods of conflict mediation (Pedersen, 2014).

\section{THE CONTRADICTORY ROLE OF THE STATE}

Popular discourse about states implementing externally advocated reforms often poses them either as powerless in the face of international financial institutions and corporations or as corruptly complicit in the exploitation of their own citizens. At least in the Tanzanian experience, the situation is much more complex. While Tanzania has definitely undergone pressure from various international actors, there is little empirical evidence indicating, for instance, that Tanzania implemented its land reforms due to donor demands. In fact, Pedersen points out that Tanzania's reforms were motivated by internal political processes, though certainly encouraged by donors (Pedersen, 2015). 
Concerning reform objectives, one could definitely say that the state is conflicted. On one side, it has taken steps seeking to strengthen citizens' rights to land vis-à-vis their own government, and there are indications that these are more than just appeals. Among other things, individuals, empowered by new legal protections, have been winning in court cases against the state itself (Ujamaa Community Resource Team). On the other hand, a great deal of land appropriation continues to take place, often for the purpose of foreign investment, an objective the government explicitly acknowledges guided the reforms (the central government has in fact explicitly stated regrets about the difficulty of obtaining land for investors!) (Stein \& Cunningham, 2015). Among other things, large-scale agricultural initiatives, such as the Southern Agricultural Growth Corridor of Tanzania (SAGCOT), have been a source of concern for citizens fearing appropriation. Recent estimates state that there are more than 1,000 land disputes annually involving confrontations between investors and villagers (Kasumuni, 2012). Much of the blame here is also leveled at the government for its lack of enforcement and abuses of power, including eviction without compensation.

\section{PRACTICE IN TANZANIA}

Studies carried out more recently provide information on the law's actual implementation. Evaluations differ quite significantly, making it difficult to make general conclusions, in combination with the fact that any large area will have variations in outcomes. In a paper presented to the World Bank in 2012, Elizabeth Fairley states that there is no empirical evidence that the government has intentionally redrawn village boundaries to appropriate land. However, she does state that land formalization has resulted in other conflicts. In situations where boundaries previously were typically ambiguous, formalization has often led to bitterness between villages, as formalization officially excludes others from land in a way that customary use does not, and a party can feel aggrieved when land it considered rightfully its own is formalized in someone else's name. Furthermore, due to the necessity of formalizing village boundaries to be able grant CCROs, in combination with the slow pace of bureaucratic processes, villages often end up acquiescing on their claims just as a matter of practicality. She lists multiple examples in pilot areas, including disputes over access to sacred sites and the encroachment of one village onto another's farmland (2012).

An issue Fairley discusses in depth is the use of land as collateral and the impact of that on desires for formalization. As she describes, landholders in the implementation pilot project areas in general did desire to formalize their land, but in most instances, their sole motivation was the possibility of using their land as collateral to obtain loans. This fact would support de Soto's argument in favor of widespread formalization, although, interestingly, the most common reason stated to want to take out a loan was actually to pay children's school fees, not for investment in agriculture or business. However, most people interviewed by Fairley were rather uninformed on the details and conditions of loans, specifically the possibility of losing one's land if one defaulted on the loan, indicating the possibility (in support of Manji's argument) that formalization could lead to a greater amount of landless rural poor. Moreover, most people who did formalize their land did not succeed in getting loans approved by banks anyway, so interest in formalization fell over time. This was compounded by the fact that later applicants had to bear a greater cost of the formalization themselves, as certifications in the first pilot projects were fully covered by World Bank funds. The concern that formalization benefits those with greater economic means is well-founded in Tanzania; Fairley notes that, in her case studies, it appears to be that landholders with greater means more frequently obtain CCRO's, as the cost of filing can deter those with lesser means (2012).

\section{DEMOGRAPHICS AND LAND CONFLICTS}

One issue that formalization does appear to aggravate is that of competing claims to land due to demographic shift and increasing pressure on land. Tanzania's population has increased from eleven million in 1963 to over forty-five million currently. Although it has a relatively low population density in comparison to other countries, this growth is significant and has undoubtedly increased competition for resources where there was previously less need for competition (challenging traditional views of Tanzania, and indeed Africa overall, as a place where land is always abundant) (Odgaard, 2002). Furthermore, various factors, including resettlement during the colonial and post-colonial periods, economic change and increased mobility, and geographic differences in resource endowment and population density, have caused significant demographic shifts throughout the country. This has brought ethnolinguistic groups into locations new and traditionally "foreign" to them, at times resulting in tension with groups living there longer. Pastoralists in particular have extended their geographic range of residence and migration (Kitabu). In a discussion on settlements in Iringa Region in southwest Tanzania, Rie Odgaard notes the distinction made by many residents between wenyeji (locals) and wageni (foreigners/outsiders, i.e., those who have migrated in more recent years to the region). The distinction between belonging to the wenyeji or wageni has a significant effect on the social legitimacy of one's claim to customary land, and with increasing pressure on land, people have started appealing to indigenous customary rights. Indigeneity would not be seen as so significant were there less pressure on land (Odgaard, 2002).

In a more tragic case, Maasai herders (whose traditional homeland is considered to be north-central Tanzania, in an area comprised of Arusha and Manyara Regions and close to many famous game reserves) have recently extended their migrations down to Morogoro Region in central- 
eastern Tanzania. Throughout that region, there have been recurrent clashes between pastoralists and farmers, at times leading to fatalities. Pastoralists are blamed for degrading the environment through overgrazing and misuse of water sources (Kitabu, 2012) and letting their herds trample crops (Makoye, 2014), as well as bribing local officials. Many point to governmental inadequacy and corruption as an ultimate cause; officials, in violation of the Land Acts, evict pastoralists to clear space for investment without compensating them, forcing them to move elsewhere. In accordance with the 1999 Acts, villages should have a land use plan to prevent disagreement on land use, but many have not drawn one out yet (Makoye, 2014).

\section{COMMUNAL LAND RIGHTS}

Large-scale land appropriations and forced evictions are not new in Tanzania or Africa, and they took place at a large scale during the colonial and post-colonial periods for various reasons. However, the growth of private investment by both foreigners and nationals is particularly concerning for many reasons, especially in light of increasing competition for resources. Although the Village Land Act does allow for land appropriation, which has been carried out unfairly many times in practice, certain provisions have enabled local residents to defend their claims in actual practice. In a liberalized age, non-governmental and civil society organizations, both national and international, have been able to play an important and at times successful role in defending rights of vulnerable groups. An innovative right in the 1999 Village Land Act is the possibility of issuing a Certificate of Customary Right of Occupancy to an entire group, making it possible for groups such as pastoralists to secure access to communally-held land. Typically, communal land is defined in village land use plans (if these have been drawn up). However, Village Councils can easily change the designation of this land (which is often seen as unused and abundant with resources), which can happen when pastoralists are a minority. A defense against this would be a group CCRO, provided for in the 1999 Acts; however, the first group CCRO in all of Tanzania was issued only in 2011 (Ujamaa Community Resource Team). The Ujamaa Community Resource Team (UCRT), working in northern Tanzania, successfully secured group CCROs for four different pastoralist and hunter-gatherer tribes, including the Hadzabe and Maasai, securing over 300,000 hectares overall (Goldman Environmental Foundation, 2016). The group CCRO makes it difficult to subdivide land (an important protection in the case of communal land), as all users must agree to the subdivision. This model shows potential applicability throughout Tanzania and could be an important strategy for otherwise vulnerable pastoralists. In fact, a UCRT program director, Edward Loure, won the 2016 Goldman Environmental Prize for Africa for his work with pastoralists and communal land (Goldman Environmental Foundation, 2016), group CCROs listed as one of his main achievements. This could be of great significance for pastoralists, who have disproportionately suffered eviction for the formation of national parks and game reserves. Forced eviction, both of pastoralists and farmers, has often taken place, and continues to do so, often under environmental pretexts (Kitabu, 2012).

\section{CONCLUSION}

Tanzania's experience with land reform, in combination with current demographic and economic trends, has been quite varied, showing both steps toward inclusiveness and signs of dispossession. This is the case when appeals to transparency are accompanied by lack of implementation and abuse of power and when decentralization is simultaneously encouraged and contained. The state and central government is arguably the actor with the most agency; however, its capacity is more limited in practice than in theory, and one must keep in mind that it is not a unified, homogeneous actor, as neither are international donors. The current situation with land rights does provide many instances of problems arising from the combination of a neoliberal/pro-poor framework to a new context but also the results of well-meaning actors aiming to reconcile various realities. Many of the issues occurring today are not uniquely due to the reforms, but they do still speak to a changing political and economic environment. Future developments may indicate a strengthening and harmonization of rights, or they may not.

\section{AUTHOR INFORMATION}

All correspondence should be sent to the first author:jjdelval@ indiana.edu.

\section{REFERENCES}

Federal Ministry for Economic Cooperation and

Development. (2006). Pro-Poor Growth: A Focal Point of Development Policy. Retrieved from https://www. bmz.de/en/publications/archiv/type_of_publication/ strategies/Special146e.pdf

Goldman Environmental Foundation. (2016). Q\&A with Edward Loure. Goldman Prize. Retrieved from http:// www.goldmanprize.org/blog/qa-edward-loure/

Fairley, E. (2012.) Upholding Customary Land Rights Through Formalization: Evidence from Tanzania's Program of Land Reform, presented at the Annual World Bank Conference on Land and Poverty, Washington, D.C., 2012. Washington, D.C.: The World Bank.

Kasumuni, L. (2012, March 2). Concern over rising number of land disputes in Tanzania. Farmland Grab. Retrieved from http://www.farmlandgrab.org/20120

Kitabu, G. (2012, November 11). Three sides of Kilombero evictions drive: Rare species, cattle burden, foreign investments. Just Conservation. Retrieved from http:// 
www.justconservation.org/three-sides-of-kilomberoevictions-drive-rare-species,-cattle-burden,-foreigninvestments

Makoye, K. (2014, January 16). Tanzania Struggles to End Clashes Between Farmers and Herders. Inter Press Service News Agency. Retrieved from http:// www.ipsnews.net/2014/01/tanzania-finds-hard-stopfarmers-herders-fighting-resources/

Manji, A. (2006). The Politics of Land Reform in Africa. London, U.K.: Zen Books.

Mirowski, P. (2009). Postface: Defining Neoliberalism. In P. Mirowski \& D. Plehwe (Eds.), The Road from Mont Pèlerin: The Making of the Neoliberal Thought Collective (pp. 417-455). Cambridge, MA: Harvard University Press.

Odgaard, R. (2002). Scrambling for Land in Tanzania: Process of Formalisation and Legimisation of Land Rights. The European Journal of Development Research, 14(2), 71-88.

Pedersen, R. H. (2015). Acess to Land Reconsidered: The Land Grab, Polycentric Governance and Tanzania's New Wave Land Reform. Geoforum, 72, 104-113. doi:10.1016/j.geoforum.2015.12.010

Pedersen, R. H. (2014). Tanzania's New Wave Land Reform: A Matter of Institutionalisation. Danish Institute for International Studies. Retrieved from http://www.diis.dk/files/media/publications/import/ institutionalisation_final.pdf

Rwegasira, A. (2012.) Land as a Human Right: A History of Land Law and Practice in Tanzania. Dar es Salaam, Tanzania: Mkuki na Nyota.

Stein, H., \& Cunningham, S. (2015). Land Grabbing and Formalization in Africa: A Critical Inquiry. (African Studies Center Working Paper No. 124/2015).

Retrieved from https://openaccess.leidenuniv.nl/ bitstream/handle/1887/37024/ASC-075287668-372201.pdf?sequence $=2$

Ujamaa Community Resource Team. (n.d.). Securing Communal Land Tenure in Northern Tanzania Using Certificates of Customary Rights of Occupancy. Retrieved from http://www.ujamaa-crt.org/ uploads/1/2/5/7/12575135/ucrt_ccro_brief_2014.pdf

Wily, L. A. (2003). Community-based Land Tenure Management: Questions and Answers about Tanzania's New Village Land Act, 1999. (International Institute for Environment and Development Drylands Programme No. 120). Retrieved from http://pubs.iied.org/ pdfs/9295IIED.pdf 
